\title{
5. Family policy support for the earner-carer and traditional-family models in Lithuania and Sweden ${ }^{1}$
Katharina Wesolowski, Sunnee Billingsley and Gerda Neyer

\section{INTRODUCTION}

Social policies are a key tool governments have to address societal developments and respond to social needs. How policies shape behaviour and social structures is a fundamental question in understanding intended and unintended effects of policies. For example, low fertility is one issue that has worried policy-makers, as it has become a widespread feature of post-industrial Eastern and Western countries since the last quarter of the 20th century. Low fertility contributes to a shrinking labour force, and many fear this might make it difficult to sustain an ageing population. Family policies have been suggested as a remedy to low fertility because they offer support to families. This support may affect the division of paid and unpaid work in the family to different degrees. Family policies can support a stay-at-home-mother/male-breadwinner family - that is, a gender-traditional family - and/or a family in which both parents are in paid work and share the upbringing of their children; that is, an earner-carer family.

Discussions among researchers and policy-makers, however, have not only been about a remedy for low fertility, but also about gender equality. McDonald (2000) and Goldscheider et al. (2015) argue that supporting both partners' earning and caring and enhancing gender equality may be a precondition to increased fertility. They maintain that as long as women have to do most of the unpaid work at home at the same time as being in paid work, a common feature of post-industrial societies, they will rather forego childbearing than shoulder the dual burden of work and care, or give up employment altogether for having children (England 2010; Goldscheider et al. 2015; McDonald 2000). Therefore, family policies facilitating the combination of 
paid and unpaid work for both mothers and fathers would make it easier for couples to have the number of children they want.

Research has shown that family policies may have an impact on fertility, but the results are not consistent (Gauthier 2007; Neyer 2005). We take the discussion around family policy effects on fertility as a starting point for thinking about how policies are measured and assessed. We argue that the conceptualisations and measurements of family policy have contributed to this inconclusiveness. For example, some research has used gender regimes to denote a country's support for different family models (Pfau-Effinger 1998). Classifications based on regime types make it difficult to capture how family policies vary over time. There is also the danger that regime-type approaches mix causes and outcomes in their typologies (see the argument in Korpi and Palme 1998). Another example is the conceptualisation of family policies on a continuum from support of a gender-traditional family model to support of an earner-carer family model (Mandel and Semyonov 2006). The drawback here is that countries' family policies can support both family types simultaneously to different degrees. Lastly, the use of expenditures on family policies in total, on single policies or on combinations of policies as measures (see, for example, Luci-Greulich and Thévenon 2013), has the drawback that it captures governmental spending, not the amount to which individuals are entitled.

Thus, we argue that in order to assess the impact of policies, we need a different approach towards the measurement of family policies. First, we need to acknowledge an essential feature of family policies, namely that they are multidimensional (see Ferrarini 2003; Korpi 2000). Multidimensionality refers to two aspects: On the one hand, it denotes that family policies usually comprise several policies that may belong to different policy fields, such as parental leave policies, child subsidies and tax policies. On the other hand, it signifies that family policies may have different functions, such as supporting a gender-egalitarian or a gendered family model. Often the functions are not clear-cut; they may be ambivalent or even contradictory. Some policies may support a gender-egalitarian behaviour and others a gendered behaviour. Second, we need to acknowledge that family policies are time-variant. Changes in family policies may shift the functions of those policies, for example, towards more forceful support of a gender-egalitarian family behaviour or towards a stronger support of a gendered family model. Third, we also need to consider what individuals can expect to receive when they have a child, and whether this support backs a more gender-egalitarian childrearing behaviour or a traditional gender-divided family form. To study the link between family policies and fertility we need measures that capture these various dimensions of family policies. The Social Policy Indicator database (SPIN) provides such measures. SPIN is a longitudinal database that acknowledges a variety of different policies that support families. Moreover, it gives the 
possibility to synthesise these policies into indicators of two types of family support simultaneously offered in many countries, and thus captures not only what a prospective parent can expect to receive when on leave with a newborn child, but also what share of the support favours a gendered and what share a gender-egalitarian behaviour.

In this chapter, we explore these harmonised data on social policies over time to describe how policies support earner-carer and traditional-family models in Lithuania and Sweden. We use these cases to describe how measures of earner-carer and traditional-family support have been constructed, and compare the policy developments over time. We highlight areas of convergence and divergence in family policy in these two countries with very different histories. We introduce the logic behind the SPIN data in the next section, detailing which policies fit within the two measures and how they are calculated. We then describe the measures specifically as they refer to Lithuania and Sweden from 1995 to 2015, illustrating both how the measures reflect the policies and how support for earner-carer and traditional-family arrangements have shifted over time in the two cases. These developments in Lithuania and Sweden are then contextualised by locating them among other Baltic and Nordic countries for which these measures have been produced in the SPIN database. Finally, we discuss the convergences and divergences we observe in Lithuania's and Sweden's family policy development, both in relation to each other and in relation to Baltic and Nordic countries.

\section{BACKGROUND: THE SOCIAL POLICY INDICATOR DATABASE}

Contrary to most other databases, SPIN is a theory-driven database. It is based on the so-called institutional or social rights approach (Ferrarini 2003; Korpi 2000; Nelson et al. 2020). This approach to classifying social policies builds on T. H. Marshall's idea of social citizenship and the social rights citizens of a country have as written in country legislation. According to Marshall (1950), citizens in a country have civil, political and social rights. He argues that social citizenship entitles citizens to at least a basic level of welfare. Building on that idea, Korpi and Palme (1998) developed indicators ${ }^{2}$ that are based on legislation of social insurances, capturing what citizens are entitled to receive when they are not able to be in paid work. An important indicator developed in this connection is what a typical worker earning an average production worker's wage is entitled to receive in a percentage of her/his wage, called the replacement rate.

In regard to family policies, Korpi (2000) created a typology based on both the institutional or social rights approach and a gender approach. This typology captures the degree to which family policies support a gender-equal 
and/or a gender-traditional division of paid and unpaid work. Countries were said to have earner-carer forms of family support when their policies attribute high levels of support to earner-carer families, in which both partners work and share childrearing, and when they have low levels of support for a gender-traditional family behaviour. When low support is given to both types of division of work in the family, countries are said to have market-oriented family policies. When high levels of support are directed to a gender-traditional division of work in the family, and low support is allocated to an earner-carer family, countries are deemed to have traditional-family policies. When high support is assigned to both family arrangements, countries are said to have a contradictory family policy model (see Ferrarini 2003; Korpi 2000; Korpi et al. 2013). This approach accounts for the multidimensionality as well as the potential ambiguities of family policies by measuring the extent to which both family arrangements are supported in a country. Moreover, it allows policies to change over time and does not use static regime types. Finally, it avoids the use of expenditures that measure total governmental spending on families by taking into account what individuals can expect to receive.

The information in the Parental Leave Benefit dataset (see endnote 2) builds on this logic. Here replacement rates are calculated for every fifth year for parental leave insurance, childcare leave and child benefits given in cash and through tax deductions, as well as tax rebates given to a male breadwinner, also called marriage subsidies.

The model family used for the calculation of the replacement rates consists of two grown-ups and two children. One of the children is the newborn for which one of the parents is on leave; the other child is below school age. The inclusion of a second, older child in the model family allows the measure to estimate what is allocated to a two-child family in cash child benefits, where some allocations depend on the age of the child.

Parental leave insurance is the income-related benefit paid to the parent on leave after the birth of a child, including income-related maternity leave benefit. To meet the eligibility requirements for income-related parental leave benefits in all countries, the parent on leave is assumed to have worked for two years on an average production worker's wage before going on leave with the newborn. Since the amount of parental leave payment, the length of payment and sharing options between parents differ among countries, the measures in the Parental Leave Benefit dataset are standardised in the following way: Information on leave weeks allocated to the mother, the father and leave that can be shared among the parents is collected and summarised. In addition, the level of the weekly and yearly income-related benefit in a country's currency is collected both gross and net of taxation. The information on cash benefits and duration per week and during the first year after the child's birth is then used to calculate weekly and yearly replacement rates. The net replacement rate for 
the first year after the child's birth is used to denote the extent of a country's support for earner-carer families, called earner-carer support.

To classify earner-carer vs. traditional gender support, the Parental Leave Benefit database distinguishes between income-related parental leave benefit and childcare leave. Childcare leave is a benefit mostly given in low flat-rate amounts, not related to previous employment, for leave after the termination of the income-related parental leave. Childcare leave information is collected in a similar way as parental leave; however, the yearly standardised replacement rate for the duration of the childcare leave benefit is calculated for the 12-month period after the termination of the income-related parental leave. Cash and fiscal child allowances, as well as maternity grants and marriage subsidies, are calculated as yearly sums, which are then divided by both the gross and net yearly wage of an average production worker. The net replacement rates for childcare leave and child allowances given in cash and through the tax system, as well as maternity grants and marriage subsidies, are summed up to reach the replacement rate denoting the extent of support to a traditional family with a stay-at-home mother and a working husband, called traditional-family support. ${ }^{3}$

One advantage of calculating a yearly replacement rate in this manner is that the measure takes into account both the taxation and duration of benefits. Taking taxation into account avoids mixing taxable and non-taxable benefits that could bias comparisons between countries (Ferrarini et al. 2013). Moreover, accounting for the duration of benefits avoids giving too much weight to high replacement rates with short duration. These result in lower replacement rates when the duration is short. So, 100 per cent replacement over 10 weeks will result in a lower annual replacement rate compared to 70 per cent over 40 weeks. Finally, the approach also uses legislated benefit ceilings instead of formal replacement rates that do not account for earnings ceilings that might take effect for an average production worker in some of the countries (Wesolowski and Ferrarini 2018).

The information used to construct the measures is taken from various sources, both international and national ones. One frequently used source is Missoc, the Mutual Information System on Social Protection of the European Union (see www.missoc.org). For countries associated with the Council of Europe, MISSCEO (Mutual Information System on Social Protection of the Council of Europe; www.missceo.coe.int) has been used as a source. SSPTW, Social Security Programs Throughout the World, published by the United States Social Security Administration in collaboration with the International Social Security Association, is another repeatedly used source (www.ssa .gov/policy/docs/progdesc/ssptw/). For the calculation of net wages and replacements, information from the European Tax Handbook from the IBFD 
(International Bureau of Fiscal Documentation, www.ibfd.org/) has been extremely helpful throughout the years.

\section{COUNTRY COMPARISON}

\section{Lithuania}

\section{The development of family policies in Lithuania since 1990}

According to Stankūnienè and Juknienè (2009), Lithuanian family policy began forming a few years before the Soviet Union broke apart and Lithuania became an independent country in 1991. Before the break-up of the Soviet Union, Lithuania was a Soviet republic during most of the 20th century and, therefore, had the same family policy as other republics (Stankūnienè and Jukniene 2009). The goal for the development of Lithuanian family policies was to improve the economic situation of families with children, but policy-makers also advocated that parents were responsible for the upbringing and well-being of their children, not the state (Aidukaite 2006). However, after the decline of fertility to its lowest low levels at the beginning of the 2000s, more pronatalist goals entered into family policy formation (Stankūnienè and Juknienè 2009).

As early as 1989, the partly paid parental leave was expanded until the child turned 18 months old, while unpaid leave was extended until the child turned 3 years old. Although the Population Programme of Lithuania, developed by researchers and policy-makers, suggested family policies that expanded the opportunities for parents to reconcile work and care, the conservative government in power opted to support stay-at-home mothers. Between 1990 and 1992 it introduced a number of low paid benefits for families to promote a gendered family behaviour. At the same time, many pre-school institutions were closed down (Stankūnienè and Juknienè 2009). Family policy goals changed again with the Social Democratic Party coming to power in 1993. In 1994, under the influence of international and national initiatives, steps were taken to emulate the family policy of social-democratic welfare states. This implied a turn to reconciliation policies supporting the combination of paid work and childcare for both women and men (Stankūnienè and Juknienè 2009), in our typology called earner-carer support. However, in 1996 a conservative government came to power and the system of low paid benefits was expanded, while policies supporting work-family reconciliation were neglected, but not abandoned. After 2001, when a government that was rather social-democratically influenced came to power, work-family reconciliation policies were expanded, but the maternity (birth) grant as well as child benefits were also increased (Stankūnienè and Juknienè 2009). As an example, the age span for the child cash benefit was expanded from the child's third to seventh birthday 
in 2004 (Aidukaite 2006). Since 2006, fathers are entitled to receive a paternity benefit ('daddy days') with a replacement rate of 100 per cent of earnings for the first month after a child's birth. Moreover, as of 2008, the maternity and parental leave benefits amount to 100 per cent of a wage during the first year and 85 per cent for the second year (Stankūnienè and Juknienè 2009).

Since independence, changes in government thus led to inconsistencies and changes in goals and ideas from a conservative and rather patriarchal focus on traditional-family support to a more social-democratic focus on earner-carer support. According to Stankūnienè and Juknienè (2009), this seems to be typical for the other Baltic countries as well. However, overall one can see an expansion of what in our typology is called earner-carer support in Lithuania. According to Aidukaite (2006), Lithuania has more means-tested benefits inherited from the Soviet system compared to other Baltic countries. The reliance on means-tested benefits also became clear in interviews with social policy experts. The experts tended to emphasise that targeting benefits to families in need would be more efficient in alleviating poverty and less expensive for a country with restricted financial resources (Aidukaite 2006). This emphasis on means-tested benefits also seems to have been met with approval by the population (Aidukaite 2004).

Aidukaite (2019) states that after the financial crisis of 2008-2010, retrenchment of social policies took place and, especially in the field of family policy, family benefits were cut back. Earnings-related maternity and parental leave benefits were reformed, and parents can now choose between a one-year leave at 100 per cent replacement of earnings or two years' leave with a rate of 70 per cent of previous earnings during the first year and 40 per cent of earnings during the second year. The paternity leave of one month after the child's birth has been kept in place (Aidukaite 2019). Thus, in terms of the typology used in this paper, it is rather the traditional-family support that decreased, while earner-carer support increased and was diversified.

\section{Earner-carer support and traditional-family support in Lithuania, 1995-2015}

Using SPIN data, we describe family policies in Lithuania from 1995 to 2015 using the typology of earner-carer and traditional-family support, as defined in the background section. Figure 5.1 shows the replacement rates of earner-carer support and traditional-family support from 1995 to 2015 for every fifth year. The replacement rates show how much an average production worker can expect to receive in per cent of her/his annual net wage when on leave with the newborn (second) child.

In 1995, earner-carer support was made up of eight weeks maternity leave at a replacement rate of 100 per cent and 44 weeks of shareable dual parental leave at 60 per cent of previous earnings until the child's first birthday. 


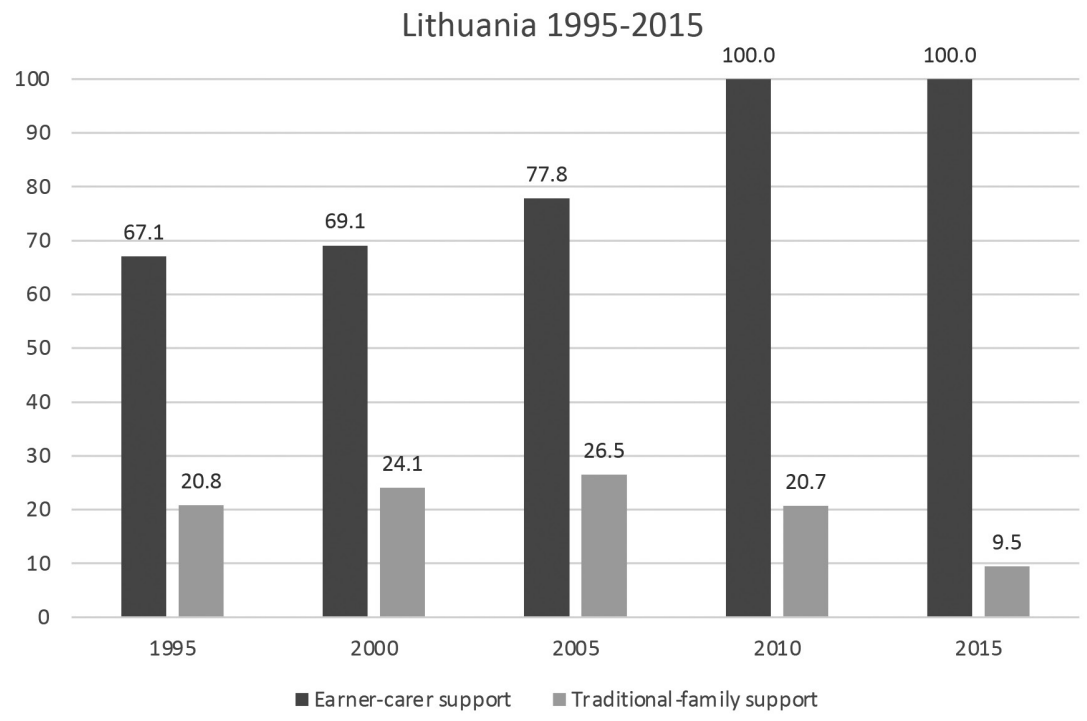

Source: SPIN, 2019 (partly unpublished data).

Figure 5.1 Earner-carer support and traditional-family support in Lithuania, 1995-2015

Therefore, an average production worker could expect to receive around 67 per cent of an annual net wage (4,326 Lithuanian litas, or LTL) for the first year after the child's birth. Traditional-family support was made up of a maternity grant of 360 LTL and 540 LTL in cash child benefit in total for 12 months, summing up to almost 21 per cent of an annual net wage for an average production worker. ${ }^{4}$

In the year 2000, as in 1995, earner-carer support consisted of eight weeks maternity leave at a replacement rate of 100 per cent and 44 weeks of shareable dual parental leave at 60 per cent of previous earnings until the child's first birthday. So, an average production worker could expect to receive 69 per cent of an annual net wage (7,790 LTL) for the first year after the child's birth. An earnings ceiling was in place, but the average production worker's wage did not hit the ceiling. Traditional-family support comprised a maternity grant of 750 LTL and 1,125 LTL in cash child benefit in total for 12 months, summing up to around 24 per cent of an annual net wage for an average production worker. $^{5}$

In the year 2005, earner-carer support was made up of eight weeks maternity leave at a replacement rate of 100 per cent and 44 weeks of shareable dual parental leave at 70 per cent of previous earnings until the child's first birth- 
day. An average production worker could then expect to receive 78 per cent of an annual net wage (11,146 LTL) for the first year after the child's birth. An earnings ceiling was in place, but the average production worker was not affected by it. Traditional-family support was made up of a maternity grant of 1,000 LTL, 1,725 LTL in cash child benefit and 229 LTL in fiscal child benefit in total for 12 months, summing up to almost 26.5 per cent of an annual net wage for an average production worker. ${ }^{6}$

For 2010, earner-carer support encompassed eight weeks maternity leave at a replacement rate of 100 per cent and 44 weeks of shareable dual parental leave at now 100 per cent of previous earnings until the child's first birthday. An average production worker could now expect to receive 100 per cent of an annual net wage (18,155 LTL) for the first year after the child's birth. Again, the earnings ceiling did not affect the average production worker. ${ }^{7}$ Traditional-family support was constituted of a maternity grant of 1,000 LTL, 1,794 LTL in cash child benefit and 540 LTL in fiscal child benefit in total for 12 months, summing up to almost 21 per cent of an annual net wage for an average production worker. ${ }^{8}$

In 2015, Lithuania joined the Euro zone. Earner-carer support consisted of a maternity leave at 100 per cent of earnings paid for eight weeks after birth. Thereafter, parents could draw dual parental leave at 100 per cent of earnings until the child turned 1 year old. An average production worker could expect to receive 100 per cent of an annual net wage (6,662 EUR) for the first year after the child's birth. The average production worker's wage did not hit the earnings ceiling. ${ }^{9}$ Traditional-family support comprised a maternity grant of 418 EUR plus 216 EUR in fiscal child benefits in total for 12 months, summing up to a mere 9.5 per cent of an annual net wage for an average production worker. ${ }^{10}$

\section{Changes over time captured in the measure}

As Figure 5.1 shows, the level of earner-carer support increased gradually from around 67 per cent to 100 per cent of an average production worker's yearly net wage from 1995-2015. However, the level of traditional-family support first increased from around 21 per cent in 1995 to almost 27 per cent in 2005, only to clearly decrease down to around 10 per cent in 2015. This mirrors the description of Stankūnienè and Juknienè (2009) of a shift in focus of family policy depending on which parties were in power. The focus on traditional-family support increased, while earner-carer support stayed about the same until it was clearly increased under a social-democratically influenced government. By 2015, the replacement rate for traditional-family support had decreased, which Aidukaite (2019) attributes to the economic crisis that took place in 2008-2010. We need to point out that the development of the replacement rate does not solely reflect increases or decreases of bene- 
fits and thus political decisions about family benefits. The replacement rate is also driven by the development of the average production worker's wage. For example, between 2005 and 2010 wages increased substantially, while benefits increased only slightly. The result of these different developments is that cash benefits in 2010 replaced a lower share of an average production worker's wage than in 2005 despite the increase in benefits.

\section{Sweden}

\section{The development of family policies in Sweden since 1990}

According to Kälvesten (1955), family policy in Sweden was expanded after Alva and Gunnar Myrdal drew attention to the risk of depopulation in their seminal book Kris $i$ befolkningsfragan (Crisis in the Population Question) in 1934. Most relevant for our comparison is the income-related, gender-egalitarian parental leave insurance that was first introduced in 1974 and was developed mostly by the social-democratic and liberal parties (Ferrarini and Duvander 2010). Nevertheless, we will concentrate on the developments since 1990 to give the reader the possibility to compare the development of family policies in Sweden and Lithuania during the same time period.

During the economic crisis in the 1990s, the level of the parental leave benefit was cut back to 75 per cent and then increased again to 80 per cent of the pre-leave wage (Ferrarini and Duvander 2010). At the end of the rule of a coalition of conservative and liberal parties from 1991 to 1994, the government announced that one month of parental leave would be reserved for each parent, becoming effective by 1995 . The same year, shortly before the social-democratic party regained power, a home-care allowance was introduced, but was in place for only a few months. In 2002, during the social-democratic rule, the reserved period for one parent was extended from one to two months, and the duration of parental leave from 15 to 16 months. Thirteen months were paid at 80 per cent of pre-leave income, while three months were paid at a low flat-rate amount. ${ }^{11}$

By 2008, the centre-right government that had come to power in 2006 revived the home-care allowance of the early 1990s. The new regulation permitted municipalities to pay a flat-rate allowance of maximally 3,000 SEK per month for children up to age 3 provided they did not use public childcare. The home-care allowance constituted a paradox among the otherwise gender-egalitarian, labour-market oriented earner-carer Swedish family policies (Lundqvist 2011). To counter this move towards a traditional-family model, the government introduced a tax relief for couples in which the father used more than the legally allocated share of parental leave, the so-called 'gender-equality bonus' (Ferrarini and Duvander 2010; Lundqvist 
2011). Ferrarini and Duvander (2010) warned that the introduction of the home-care allowance might lead to increased inequality in care and undermine the gender-egalitarian reconciliation of work and childrearing. Neither the home-care allowance nor the gender-equality bonus gained popularity. Only half of the municipalities offered the home-care allowance benefit, and only 4 per cent of all parents took it; 90 per cent were women and most had only a weak attachment to the labour market (Duvander and Ellingsæter 2016). Not least because of an initially complicated regulation, the gender-equality bonus was equally unsuccessful. It did not immediately or noticeably increase fathers' use of parental leave or promote gender equality (Duvander and Johansson 2012).

When the social-democratic party regained power with the help of the Green and Left parties, it abolished the home-care allowance in 2016 (Sveriges riksdag 2016), and the gender-equality bonus in 2017. Instead, in 2016 it extended the reserved part of parental leave to three months, so that the current regulation allocates three months of the income-related parental leave to one parent, three months to the other, and seven months that can be shared as parents prefer (Försäkringskassan 2019). The introduction and every expansion of the reserved part of the leave increased fathers' uptake of parental leave, but the most influence on fathers' uptake of parental leave was related to the first reserved month in 1995 (Försäkringskassan 2019).

Ferrarini and Duvander (2010) state that parental leave is used by basically all mothers and around 90 per cent of fathers. The high earnings ceiling ensures most parents 80 per cent of their pre-leave income. Commonly, collective bargaining agreements state that the employer pays an additional 10 per cent of the wage below the wage ceiling and, when an employee reaches the wage ceiling, the employer pays the difference to ensure a total of 90 per cent wage replacement. Since most parents are covered by a collective agreement, this substantially reduces the income loss during parental leave. Parental leave in Sweden is also very flexible; benefits are calculated in days and can be drawn in full, half-days, quarter-days or one-eighth-of-a-day shares. If a parent takes only part of a day, the leave extends accordingly. But flexibility has been reduced somewhat since 2014, as a larger part of parental insurance has to be taken before the child turns 4 years old (Duvander et al. 2015).

In Sweden, as in Lithuania and many other countries, family policy development was influenced by the political orientation of the different governments in power. Every time a more conservative government was in power, the conservative parties introduced reforms that rather supported a traditional-family model, while reforms supporting a more gender-equal division of paid and unpaid work were more on the agenda of the liberal party and strongly promoted by the social-democratic party. The practical failure of the latest 
home-care allowance demonstrated that gender equality in parental leave is by now firmly anchored in Swedish society.

\section{Earner-carer support and traditional-family support in Sweden, 1995-2015}

We now turn to a description of family policies in Sweden from 1995 to 2015 using our typology of earner-carer and traditional-family support. Figure 5.2 shows the replacement rates of earner-carer support and traditional-family support from 1995 to 2015 for every fifth year. To recall, the replacement rates denote how much an average production worker can expect to receive in per cent of her/his annual net wage when on leave with the newborn (second) child during the first year of its life.

Sweden 1995-2015

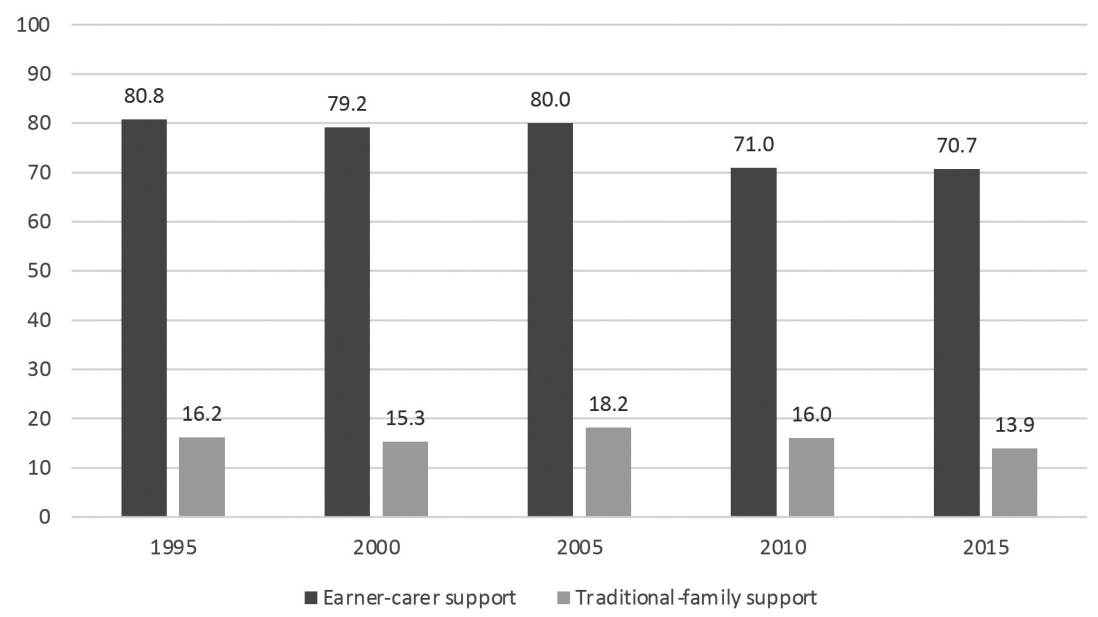

Source: SPIN, 2019 (partly unpublished data).

Figure 5.2 Earner-carer support and traditional-family support in Sweden, 1995-2015

In 1995, earner-carer support consisted of 12 months of shareable parental leave at 80 per cent of pre-leave income, with one month reserved for each parent. Therefore, an average production worker could expect to receive almost 81 per cent of an annual net wage (134,976 Swedish kronor, or SEK). Traditional-family support consisted of the three months of flat-rate paid leave after income-related parental leave at $60 \mathrm{SEK} /$ day, as well as 18,000 SEK of 
cash child benefit, amounting to a replacement rate of around 16 per cent of an average production worker's wage. ${ }^{12}$

In 2000, earner-carer support consisted of 12 months of shareable parental leave at 80 per cent of pre-leave income (156,511 SEK), with one month reserved for each parent. An average production worker could then expect to receive around 79 per cent of an annual net wage. The decline from 81 per cent in 1995 is due to differences in taxation. Traditional-family support again consisted of three months of flat-rate leave after income-related parental leave at $60 \mathrm{SEK} /$ day and 20,400 SEK of cash child benefit, summing up to around 15 per cent of an average production worker's wage. ${ }^{13}$

In the year 2005, earner-carer support consisted of 13 months of shareable parental leave at 80 per cent of pre-leave income (187,015 SEK), with two months now reserved for each parent. It is important to note that, as described in the background section, only the first 12 months of this leave are included in the SPIN measure since it is calculated as the replacement rate for the leave during the first year after the child's birth. So, an average production worker could expect to receive 80 per cent of an annual net wage. Traditional-family support still consisted of three months of flat-rate leave after income-related parental leave at $180 \mathrm{SEK} /$ day and now 22,800 SEK of cash child benefit, giving a replacement rate of around 18 per cent. ${ }^{14}$

In 2010, earner-carer support consisted of 13 months of shareable parental leave at 80 per cent of pre-leave income (239,282 SEK), with two months reserved for each parent (12 months coded). By then, however, the social insurance agency multiplied the pre-leave income by a factor of 0.97 , so that the effective gross replacement rate was 77.6 per cent. Further, changes in taxation rules with the introduction of an earned-income tax credit (EITC) led to a higher pre-leave net income. An average production worker could thus expect to receive 71 per cent of an annual net wage. Traditional-family support included the three months of flat-rate leave after income-related parental leave at $180 \mathrm{SEK} /$ day and $27,000 \mathrm{SEK}$ of cash child benefit. The net replacement rate was thus 16 per cent. ${ }^{15}$

In the year 2015, as in 2010, earner-carer support consisted of 13 months of shareable parental leave at 80 per cent, with two months reserved for each parent (12 months coded). As the same calculation rule applied in 2015 as in 2010 and the EITC was also still in effect, an average production worker could expect to receive around 71 per cent of an annual net wage $(273,445$ SEK). Traditional-family support included three months of flat-rate leave after income-related parental leave at $180 \mathrm{SEK}$ /day, as well as 27,000 SEK of cash child benefit. Since the amount of the cash child benefit had not increased, while the pre-leave income had, the replacement rate was around 14 per cent of an average production worker's net wage. ${ }^{16}$ 


\section{Changes over time captured in the measure}

As Figure 5.2 shows, there are only small changes to be seen in the strength of support to both dimensions during our observation period. Effectively, however, earner-carer support has been reduced to around 70 per cent of pre-leave net income due to changes in the calculation of benefits and tax effects of the EITC that was introduced after the change in government in 2007. The EITC is only granted on earned income, not on parental leave benefits, and thus gives a higher net income compared to before. For traditional-family support, the only changes are small fluctuations in the effect of the cash child benefit, while the three months of leave paid in flat-rate amounts had not changed during the time period.

\section{Lithuania and Sweden compared to other Baltic and Nordic countries}

The SPIN database offers measures of the degree of traditional-family and earner-carer support for many other countries besides Lithuania and Sweden. All measures were calculated in the same manner as described for Lithuania and Sweden and therefore are comparable across countries. Figures 5.3 and 5.4 display the measures of earner-carer support and traditional-family support from 1995 to 2015 for every fifth year for the Baltic and Nordic countries, excluding Iceland because it is not included in the Parental Leave Benefit data. As evident, these measures capture significant shifts over time in policy support for earner-carer and traditional-family arrangements. Earner-carer and traditional-family support for the Baltic countries is presented in Figure 5.3. In the top panel we see that Lithuania offered the most earner-carer support in the late 1990s and early 2000s, whereas Latvia offered the least. The difference was substantial, with support hovering around 70 per cent of an average production worker's wage in Lithuania and only 20 per cent in Latvia. By 2005, this gap had reversed, with both Estonia and Latvia offering almost full coverage (93 per cent in Estonia and 100 per cent in Latvia). Lithuania followed suit and offered full support (100 per cent) by 2010. This high coverage remained mostly the case thereafter, with the exception of Latvia reducing support to around 74 per cent by 2015. Less dramatic shifts in support for traditional-family arrangements are evident in the bottom panel of Figure 5.3. The trend indicates reduced support of this kind over time in Lithuania and Estonia since 2000, but levels have remained relatively steady in Latvia regardless of the marked increase in earner-carer support in the same time period.

Regarding the Nordic countries, Figure 5.4 shows that Denmark began with the lowest levels and remained at the lowest level even after a substantial increase. In the late 1990s and until even 2000, Denmark provided less than 30 per cent of an average production worker's net annual wage in the form of benefits that encouraged an earner-carer family arrangement. From the data 


\section{Earner-carer support 1995-2015, Lithuania and other Baltic countries}

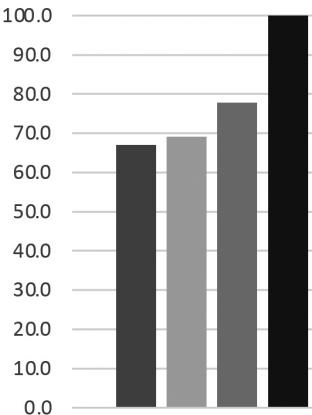

Lithua nia

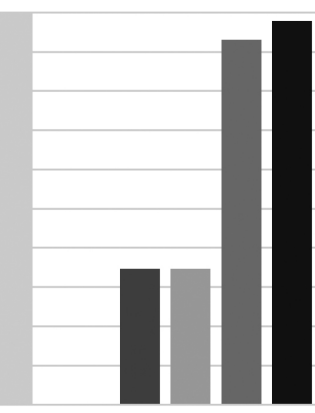

Estonia
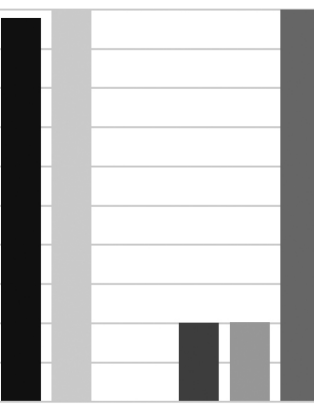

Latvia

- Earner-carer support, 1995 = Earner-carer support, 2000 E Ea rner-carer support, 2005

שEarner-carer support, 2010 - Earner-carer support, 2015

Traditional-family support 1995-2015, Lithuania and other Baltic countries

100.0
90.0
80.0
70.0
60.0
50.0
40.0
30.0
20.0
10.0
0.0
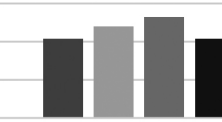

Lithua nia
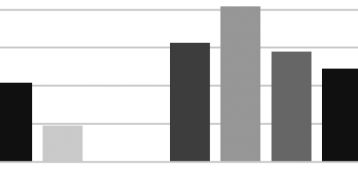

Estonia

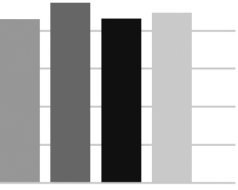

Latvia

- Traditional -family support, 1995 = Traditional-fam ily support, 2000 = Traditional -fam ily support, 2005

- Traditional-family support, 2010 = Traditional-family support, 2015

Source: SPIN, 2019 (partly unpublished data).

Figure 5.3 Earner-carer support and traditional-family support over time in the Baltic countries

point of 2005 onwards, this support had increased and hovered around 45 to 50 per cent. On the other end of the distribution, Norway consistently offered the strongest support for earner-carer family arrangements, which ranged from a low of 77 per cent in 2005 to around 89 per cent in 2015. We see a convergence between Sweden and Finland over time in which Sweden offered around 
Earner-carer support 1995-2015, Sweden and other Nordic countries

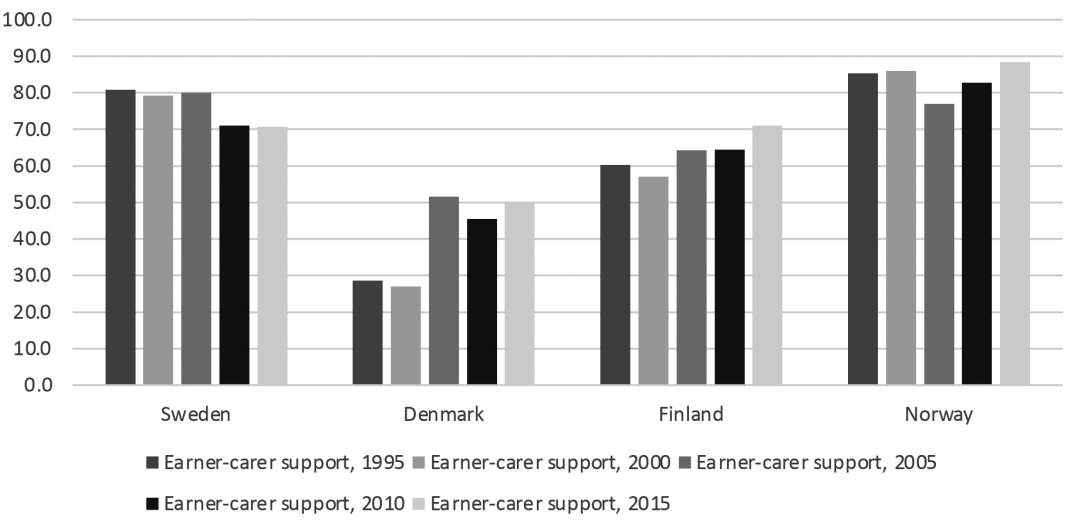

Traditional-family support 1995-2015, Sweden and other Nordic countries

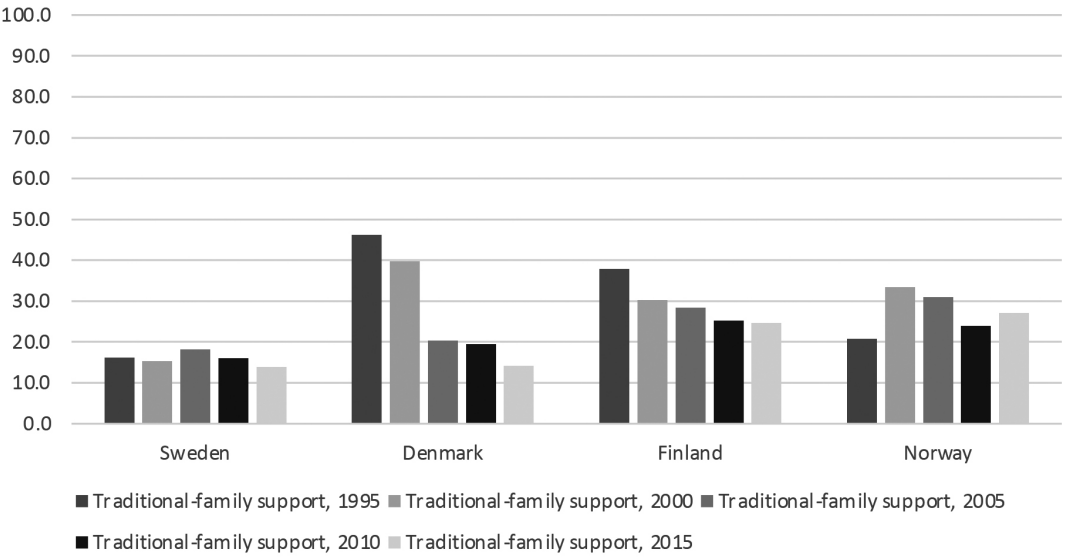

Source: SPIN, 2019 (partly unpublished data).

Figure 5.4 Earner-carer support and traditional-family support over time in the Nordic countries

20 percentage points more support in the early years measured here, but by 2015 Finland had slightly surpassed Sweden in earner-carer support. The bottom panel of Figure 5.4 shows that when support for earner-carer families decreased, support for traditional families tended to increase. In particular, we see this trend in Denmark and Finland. Traditional-family support declined 
over the years observed here in those two countries, but not in Sweden and Norway. By 2015, the difference between the Nordic countries had narrowed to a span of 14 per cent in Sweden and Denmark to 27 per cent in Norway.

Although the data reveal differences among the Nordic and Baltic countries, we still see similarities among the countries within a group, such as parallel trends or convergence. When comparing the two groups of countries to each other, we similarly see convergence towards the same levels of earner-carer support over time among them all. In 1995, the data reveal that Lithuania's policies resembled the Nordic countries' policies in terms of what a family could expect to receive in the first year following a birth, whereas Denmark's policies resembled those in the Baltic countries. As early as 2005, the Baltic countries were already leading in earner-carer support offered, and this continued until the end of our time-series. This finding may come as a surprise, as the Nordic countries are often used as examples of policies strongly supporting gender equality, instead of the Baltic countries. By 2015, however, only Denmark stood out from the countries in both groups as offering particularly low support. In terms of traditional-family support, declines by 2015 in all countries except Latvia and Norway have resulted in similar, low shares of an average production worker's wage that would be expected by families. Only Latvia stands out as having relatively high support for traditional-family arrangements in these two groups of countries. In summary, we see remarkable similarities among the Baltic and Nordic countries in the orientation of their different policies and how they support couples during the years in which they are having children.

\section{DISCUSSION}

In this chapter, we presented arguments for family policy measures that distinguish between support of gender-egalitarian earner-carer family arrangements and traditional gendered family arrangements. We used the example of fertility research to demonstrate the importance of this distinction according to prevailing fertility theories; these distinct orientations of family policies shape the division of labour in the home and have implications for women's childbearing behaviour. How couples divide home and care work has implications for other individual and family developments across the life course, lending relevance to these measures for a wide range of family and demographic research.

We outlined the principles and logic behind SPIN's complex harmonisation effort and used the cases of Lithuania and Sweden to illustrate how real policies are transformed into these measures. The development of these measures over time reflects important changes in support to families in each country. Although SPIN data may provide the best measures available for comparative research of the link between family policies and family dynamics, it is not 
without limitations, and in this section we discuss these in light of these two country contexts. We conclude by acknowledging additional advantages to what we already outlined that became evident in the course of this exercise.

First, one disadvantage with the approach adopted in the SPIN data is that it reflects only what a four-member family with one or two average production worker earners can expect after having a child. The model family approach has the advantage of being simple and reflecting the most common family norm in post-industrial countries or the reality for a portion of the population. It is also used in other indexes, such as poverty indexes. A comparison with alternative model families could inform us about potentially relevant variations in policy design. Incorporating eligibility criteria such as pre-requisites for receiving benefits and income ceilings would tell us whether there are substantial subgroups of individuals that receive a very different level of support than the average production worker model family. In particular, we could see how the replacement rate varies for groups such as high earners as well as immigrants with no work experience yet in the host country. Measures related to other model families are already being calculated by the social policy group at the Swedish Institute for Social Research. Single parents represent another model family that would be useful to explore because some countries offer specific support to these families. Moreover, given that single parents are overwhelmingly mothers, pegging the replacement rate to a wage in a male-dominated occupation (average production worker) may not yield the most accurate or generalisable information. Although the average production worker wage is widely published and easily available, it may be worth collecting information on an average female worker's wage or an average wage in areas with many women employees, such as a service worker's or public employee's wage, for example. This would also be more in alignment with the fact that it is the woman's wage in the family that is being replaced in the majority of the benefits.

A few other aspects in how well the measures represent the family policies and support different family arrangements became noticeable in the discussion of our specific case studies. The measures only consider the replacement rate in terms of one earner in a household when policies can be directed specifically to both parents as earners and/or offer support that is conditional on the other partner taking the benefit. A more complete picture of earner-carer support may therefore emerge with a replacement rate of both parents' income rather than one parent's income.

Third, the measures focus on the first 12 months after a child is born, as a way of estimating the share of a replaced annual wage. This narrow window of time can lead to an under-representation of actual support received that is relevant to the division of labour. Already, SPIN data step over the one-year boundary in an effort to capture support given through the childcare leave benefit, which 
increases the accuracy of the traditional-family arrangement measure. By not doing the same for the earner-carer measure, the SPIN data might underestimate some of the parental leave provisions, for example, if parental leave is shorter or longer than one year (see, for example, Nieuwenhuis et al. 2017). However, deciding the correct length of time to observe is not straightforward, and some policy features may always be lost. At the least, the time frame considered for calculating the measures needs to be explicitly discussed in relation to whether certain policies are excluded that may be relevant to an outcome of interest.

A fourth feature to discuss is that beyond the level of earner-carer support, the calculation of the earner-carer support measure in the SPIN data does not acknowledge policies that incentivise both parents taking parental leave. For example, it does not take into account the paternity leave that may be taken simultaneously with maternity leave. It also does not account for leave that is reserved for either parent. Considering the emphasis in contemporary theory and public discussion on gender equality in both the private and public spheres, this omission is important. Weighting the measures in terms of shareability or reserved months may be one avenue of bringing dual carer support into the measure, as would changing the construction to potentially include both parents' wages.

Finally, SPIN data are collected for every fifth year. Changes in between that may affect family behaviour are not reflected. Yearly data may provide a more accurate picture of the development of family support. An expansion of the database to annual data is already planned by the social policy group at the Swedish Institute for Social Research.

This discussion of limitations illustrates the complexity of calculating a simple, comparable measure across very different policy designs. It may also hide the advantages that SPIN data have and do injustice to those who collected them. As discussed in our introduction and the background section, other databases of comparative family support may provide some of the information we found missing in SPIN but lack other features that are essential for some types of research. To our knowledge there is no other database that provides (a) comparable, (b) standardised family policy measures (c) over time, which (d) distinguishes the aims of family policies and (e) recognises support from different policy areas in the calculation (for example, taxation, social insurance). SPIN data can be used for research on a variety of social policy issues, both at the aggregate and individual levels, and are particularly useful for comparative and longitudinal research. The exercise in comparing Lithuania and Sweden revealed a few additional advantages to highlight besides the arguments stated earlier in this chapter and the brief summary above. In the discussion of why the measures were calculated as they are, we mentioned an important principle in SPIN data, which is that measures reflect what couples 
can actually expect to receive after having a child, instead of a more abstract or aggregated level of support. This principle became even clearer when observing both changes in the policies and the measures simultaneously, because it is evident that changes in other arenas, such as taxation and wage-setting, impact the policy support. For example, we saw that two small tax-related changes essentially lowered earner-carer support by 10 percentage points in Sweden. In Lithuania, traditional-family support declined due to wage growth even when there had been small increases in benefits. These fluctuations are unintended consequences that are relevant to individuals but do not necessarily speak to any shift in policy-makers' support. They highlight the fact that individuals' experience of social insurances is vulnerable to many forces. The SPIN measures, therefore, provide an important check for analysts and policy-makers to ensure that the policy continues to provide as strong a support as was intended.

\section{ACKNOWLEDGEMENTS}

The policy measures were derived from the SPIN database, which has been extended by Katharina Wesolowski and colleagues at the Swedish Institute for Social Research. The construction of the dimensions follows Ferrarini (2003) and Korpi et al. (2013). We presented a draft of this chapter at the workshop Challenges to the Welfare State Systems in Baltic and Nordic Countries organised by Jolanta Aidukaite at the Lithuanian Social Research Centre in Vilnius, Lithuania, and would like to thank the participants for their input. Gerda Neyer acknowledges financial support by the Swedish Research Council, research grant Dnr 2020-01976, on fertility intentions, fertility considerations and fertility decline in Sweden.

\section{NOTES}

1. An earlier version of this chapter was published in Demographic Research with a more detailed description of the dataset and a comparison of more European countries (Wesolowski et al. 2020). The authors thank the editors for the permission to republish parts of the article.

2. At first, the data collected covered information from 18 Organisation for Economic Co-operation and Development (OECD) countries on four main social insurances connected to working life: unemployment, sickness, work accident and old age. As of 2019, the Social Policy Indicators database (SPIN), as it is called now, covers additional social insurance and social assistance programs for up to 34 countries (see www.spin.su.se). One of the modules included in SPIN is the Parental Leave Benefit dataset (PLB). The data available cover institutional information on parental leave insurance for 18 OECD countries from 1950-2015. For an overview over the SPIN database and planned expansions, see Nelson et al. (2020).

3. Indicators on childcare leave and maternity grants used in this chapter have been taken from an earlier unpublished version of the Parental Leave Benefit dataset. 
Data on cash and fiscal child allowances are taken from the Child Benefit dataset module, while marriage subsidies are calculated by subtracting the net wage of a single average production worker's wage from the net wage for a couple that can be found in the SIED module (Social Insurance Entitlement dataset).

4. Sources for 1995: SSPTW 1995, law on state benefits for the family 1994, law on state social insurance 1993, provisional law on income tax of natural persons 1990 (as of 1993); government regulation on minimum amounts Jan 4 1995, answer from Ministry of Social Security and Labour 26th April 2013.

5. Sources for 2000: SSPTW 1999 and 2002, Missceec 1999 and 2002, Missceo 2000, law on state benefits for families with children, answer from Ministry of Social Security and Labour 26th April 2013.

6. Sources for 2005: Missoc 2005; Missceo 2005; SSPTW 2004 and 2006; national laws; direct information; European Tax Handbook 2005.

7. There was also the possibility to continue on parental leave for one more year at 85 per cent of previous earnings, but our measure of earner-carer support only takes into account the duration of earnings-related leave during the first year after the child's birth.

8. Source for 2010: Missoc 2010.

9. Parents could choose between two options for parental leave: 100 per cent of earnings until the child is 1 year old, or 70 per cent of earnings until the child is 1 year old and 40 per cent of earnings until the child is 2 years old. For the calculation of earner-carer support, the first option, maximising parental leave during the first year, was chosen. A paternity leave (daddy days) of 1 month at 100 per cent of earnings was given simultaneously with maternity leave and is therefore not included in earner-carer support.

10. Sources for 2015: 11th International Review of Leave Policies and Related Research 2015, Missoc 2015.

11. These three months paid at a flat rate existed from 1980, when this benefit's duration was expanded from one to three months (SOU 2017:101).

12. Sources for 1995: SPIN calculations.

13. Sources for 2000: SPIN calculations.

14. Source for 2005: International Review of Leave Policies and Related Research 2005.

15. Source for 2010: International Review of Leave Policies and Related Research 2010.

16. Source for 2015: International Review of Leave Policies and Related Research 2015.

\section{REFERENCES}

Aidukaite, J. (2004), The Emergence of the Post-Socialist Welfare State: The Case of the Baltic States; Estonia, Latvia and Lithuania, Huddinge: Södertörns Högskola.

Aidukaite, J. (2006), 'Reforming family policy in the Baltic states: The views of the elites', Communist and Post-Communist Studies, 39 (1), 1-23.

Aidukaite, J. (2019), 'The welfare systems of the Baltic states following the recent financial crisis of 2008-2010: Expansion or retrenchment?', Journal of Baltic Studies, 50 (1), 39-58. 
Duvander, A.-Z., and A. L. Ellingsæter (2016), 'Cash for childcare schemes in the Nordic welfare states: Diverse paths, diverse outcomes', European Societies, 18 (1), 70-90.

Duvander, A.-Z., T. Ferrarini and M. Johansson (2015), Familjepolitik för alla?: en ESO-rapport om föräldrapenning och jämställdhet, Stockholm: Finansdepartementet, Regeringskansliet.

Duvander, A.-Z., and M. Johansson (2012), 'What are the effects of reforms promoting fathers' parental leave use?', Journal of European Social Policy, 22 (3), 319-30.

England, P. (2010), 'The gender revolution: Uneven and stalled', Gender \& Society, $24(2), 149-66$.

Ferrarini, T. (2003), Parental Leave Institutions in Eighteen Post-War Welfare States, Stockholm: Stockholm University.

Ferrarini, T., and A.-Z. Duvander (2010), 'Earner-carer model at the crossroads: Reforms and outcomes of Sweden's family policy in comparative perspective', International Journal of Health Services, 40 (3), 373-98.

Ferrarini, T., K. Nelson, W. Korpi and J. Palme (2013), 'Social citizenship rights and social insurance replacement rate validity: Pitfalls and possibilities', Journal of European Public Policy, 20 (9), 1251-66.

Försäkringskassan (2019), Reserverade Dagar Ökar Pappors Uttag Av Föräldrapenning, Korta analyser 2019:1, Stockholm: Försäkringskassan.

Gauthier, A. H. (2007), 'The impact of family policies on fertility in industrialized countries: A review of the literature', Population Research and Policy Review, 26 (3), 323-46.

Goldscheider, F., E. Bernhardt and T. Lappegård (2015), 'The gender revolution: A framework for understanding changing family and demographic behavior', Population and Development Review, 41 (2), 207-39.

Kälvesten, A.-L. (1955), 'Family policy in Sweden', Marriage and Family Living, 17 (3), 250.

Korpi, W. (2000), 'Faces of inequality: Gender, class, and patterns of inequalities in different types of welfare states', Social Politics: International Studies in Gender, State \& Society, 7 (2), 127-91.

Korpi, W., T. Ferrarini and S. Englund (2013), 'Women's opportunities under different family policy constellations: Gender, class, and inequality tradeoffs in Western countries re-examined', Social Politics: International Studies in Gender, State \& Society, 20 (1), 1-40.

Korpi, W., and J. Palme (1998), 'The paradox of redistribution and strategies of equality: Welfare state institutions, inequality, and poverty in the Western countries', American Sociological Review, 63 (5), 661-87.

Luci-Greulich, A., and O. Thévenon (2013), 'The impact of family policies on fertility trends in developed countries', European Journal of Population, 29 (4), 387-416.

Lundqvist, Å. (2011), Family Policy Paradoxes: Gender Equality and Labour Market Regulation in Sweden, 1930-2010, Bristol: Policy Press.

Mandel, H., and M. Semyonov (2006), 'A welfare state paradox: State interventions and women's employment opportunities in 22 countries', American Journal of Sociology, 111 (6), 1910-49.

Marshall, T. H. (1950), Citizenship and Social Class and Other Essays, Cambridge: Cambridge University Press.

McDonald, P. (2000), 'Gender equity in theories of fertility transition', Population and Development Review, 26 (3), 427-39. 
Nelson, K., D. Fredriksson, T. Korpi, W. Korpi, J. Palme and O. Sjöberg (2020), 'The Social Policy Indicators (SPIN) database', International Journal of Social Welfare, 29 (3), 285-89.

Neyer, G. (2005), 'Family policies in Western Europe: Fertility policies at the intersection of gender, employment, and care policies', Österreichische Zeitschrift für Politikwissenschaft, 34 (1), 91-102.

Nieuwenhuis, R., A. Need and H. van der Kolk (2017), 'Is there such a thing as too long childcare leave?', International Journal of Sociology and Social Policy, 37 $(1 / 2), 2-15$.

Pfau-Effinger, B. (1998), 'Gender cultures and the gender arrangement: A theoretical framework for cross-national gender research', Innovation: The European Journal of Social Science Research, 11 (2), 147-66.

SOU (2017:101), Jämställt Föräldraskap Och Goda Uppväxtvillkor För Barn: En Ny Modell För Föräldraförsäkringen: Slutbetänkande Av Utredningen Om En Modern Föräldraförsäkring, Stockholm: Wolters Kluwer.

Stankūnienè, V., and R. Juknienè (2009), 'Family policies in the Baltic countries: 1989-2008 - 3.1 Lithuania', in V. Stankūnienè and D. Jasilionis (eds), The Baltic Countries: Population, Family and Family Policy, Vilnius: Institute for Social Research, pp. 91-100.

Sveriges riksdag (2016), Lag Om Upphävande Av Lagen (2008:307) Om Kommunalt Vårdnadsbidrag.

Wesolowski, K., and T. Ferrarini (2018), 'Family policies and fertility: Examining the link between family policy institutions and fertility rates in 33 countries 1995-2011', International Journal of Sociology and Social Policy, 38 (11/12), 1057-70.

Wesolowski, K., S. Billingsley and G. Neyer (2020), 'Disentangling the complexity of family policies: SPIN data with an application to Lithuania and Sweden, 1995-2015', Demographic Research, 43, 1235-62. 